\title{
Connecting the Image of God as Almighty Father, Narcissism, Trump, and Charles Brockden Brown's Wieland
}

\author{
Inez Martinez
}

\begin{abstract}
Given Jung's understanding of emergence as unconscious materials unattended emerging into lived life, the election of Donald Trump to the presidency of the United States calls for analysis of unconscious collective attitudes. Trump's enthusiastic supporters embrace his narcissism, including his claims to almighty power, obedience, and adoration, claims characteristic of the God image of the Judeo-Christian Father almighty. This essay proposes that Americans socialized to worship that image of God have not been aware that they are divinizing narcissistic traits. Charles Brockden Brown's novel Wieland or the Transformation, An American Tale (1798) portrays such a God and a phantom narrative unveiling murderousness in the narcissistic divine Father-son relations. Brown concludes with a call for the development of "juster notions" of divinity. Recognizing the latent murderousness in the narcissistic image of God the Father almighty potentially leads to recalling that projection and collectively accepting responsibility for inner murderousness.
\end{abstract}

Keywords: emergence, Narcissism, God image, Father almighty, Trump, Wieland, Charles Brockden Brown, phantom narrative, American selfimage

Carl Jung warns that "when an inner situation is not made conscious, it appears outside as fate" (CW 9.ii, par. 126). Donald Trump's ascendance to the American presidency is a fate Americans did not anticipate, an emergence from collective unconsciousness demanding analytic attention. Jung's vision of psychological emergence differs from the current more general understanding of emergence in that it does not presume an evolution of order and adaptability. Joseph Cambray in his study of synchronicity discusses emergence as a move toward a higher order. Describing systems "operating far from equilibrium" interacting "with their environments" to produce "adaptive emergent properties," he explains that the "sum of the interactions ... manifest[s] new, unexpected higher levels of and order in the process of adapting to their surroundings" (45). He attributes the emergence of mind, for example, to this kind of process (46). Increase in complexity occurs when there is a breakdown in symmetry through "phase transitions," "rapid, abrupt reorganizations in a dynamic system that radically restructure the system, allowing new forms to emerge." At this point Cambray acknowledges that "psychological equivalent[s] of phase transitions and reorganizations can be highly stressful . . . even if ultimately positive in transformative effect" (64).

This idea of emergence as creative of a higher order, when applied to relations of unconsciousness and consciousness, elides the uncertainty in the consequences of unconscious material emerging into manifest intelligibility. Jung's vision assumes that 
when unconscious material becomes conscious, the possibility of choice also emerges. What choices may follow encompasses a range of possible consequences. Once the unconscious contents have become manifest, it may be possible for a higher order to emerge, but, as experience all too frequently shows, that development is not assured. The ascendance of Trump as a collective fate emerging from collective unconsciousness thus demands inquiry into what has lain unattended in collective unconsciousness, but even successful inquiry does not guarantee an evolution in order and adaptability.

Jung's framework for understanding emergence allows analysis of the implications for group psyches of emergences not leading to greater adaptability or inclusive order: e.g., unrepressed hatred of migrants and adoration of authoritarian leaders. ${ }^{1}$ In the case of Trump, his passionate supporters embrace not only his authoritarianism but also classic traits of narcissism that he embodies, as I will explore in detail.

In particular, this essay will focus on one aspect of unconsciousness not previously identified as contributing to the intransigent support of Trump's base. That aspect concerns fantasies of unlimited power, God as an almighty Father, and connections between these fantasies and classic traits of narcissism. Exposition of these connections provides the context for revisiting an early American literary production (1798), a novel by Charles Brockden Brown that portrays the projection of a punitive God as an almighty Father by a narcissistic devotee at the beginnings of the American nation. Brown's Wieland or the Transformation, An American Tale shocks in its analysis of subjection to paternal authority and implies the need for a morally evolving image of God the Father. It reveals, as Jung suggests visionary literature does ( $C W 15$, par. 141), an aspect of what needs to be made conscious in the American collective. Jung writes:

Every period has its bias, its particular prejudice, and its psychic malaise. An epoch is like an individual: it has its own limitations of conscious outlook, and therefore requires a compensatory adjustment. This is effected by the collective unconscious when a poet or seer lends expression to the unspoken desire of his times . . . regardless whether this blind collective need results in good or evil, in the salvation of an epoch or its destruction. (CW 15, par. 153)

Wieland reveals narcissistic idolization of the rule of the father at the beginnings of America, an idolization considered legitimate because it is embedded in religious worship of God imaged as almighty Father. That attitude-without the religious trappingsmanifested in the ecstatic crowds supporting Trump, is the aspect of unattended unconsciousness upon which this essay will focus.

Others before me, of course, have helped understand other aspects of the motivations of Trump's base. I want to acknowledge the contributions and explain what I consider the limitations of three notable previous analyses. Listen, Liberal by Thomas Frank details economic reasons Trump's supporters feel abandoned, no doubt a force partially accounting for their rejection of previous leadership, but one too rational to account for the rage and hatred evident at Trump rallies. Strangers in Their Own Land by Arlie Russell Hochschild, a sociologist using participant observation to get to know Trump supporters in Louisiana, metaphorically describes their sense of unfairness as waiting in a long, barely moving line to reach the top of a huge hill to achieve prosperity and security while watching the federal government assist others-blacks, other non-whites, 
immigrants, and women - cut in line $(136-40)$. As with Frank's contribution, what Hochschild offers to understanding is persuasive but partial. As a participant observer she cannot ask informants to engage the unfairness of the historic and geographic inaccessibility of the "line" to the groups being allowed in. In other words, her method excludes any possible transformation of their understanding and assumptions about unfairness. "President Trump and the American Selfie" by Jungian Tom Singer, one of the originators of the concept of the cultural complex and a theoretician of psyche shared by a group, argues that "there is a good fit between Trump's personal narcissism and the narcissism of our culture and the wounded collective Self of many Americans" (31). This pinpointing of the importance of narcissism is penetrating. His description of the American group spirit, however, fails the possibilities in the conceptual tool that he is contributing. He offers the following description of the core of the American group Self or group spirit: "The Self or group spirit of America is built on more than 300 years of progress, success, achievement, resourcefulness, and ingenuity, accompanied by almost endless opportunity and good fortune. We love and believe in our heroic potential, our freedom and independence ... a and eternal innocence" (35). As I read those lines, I stumble over the "we." Native Americans, deprived of lands and way of life, have not experienced 300 years of progress and success. Most Black Americans didn't have even freedom from slavery until a little over 150 years ago; they had little access to civil rights until a little over 50 years ago, and their right to vote is still being suppressed (Goldstone). Women still do not have a constitutional guarantee of equal rights. Gay people, their sexual alliances long criminalized, were not allowed to marry as a federal right until 2015. I could keep adding to this list, but I think the point is made. Who is the "we" in Singer's understanding of the American group spirit? It apparently excludes more than half the American people. And in so doing, it undercuts any claim of the group spirit's being "innocent."

While Singer's contribution, in collaboration with Samuel Kimbles, of the theoretical concept of the cultural complex, has been profoundly important, and his theoretical concept of a group spirit is potentially useful, his understanding of the American group spirit would be better named the white, largely Christian, primarily male-supremacist group spirit of a portion of Americans. I have addressed the sense of victimization experienced by this group in "Trump's Base, Ahab, and the American Dream." Before proceeding to analyze the power aspect of the support of narcissism by Trump's base that I wish to clarify, let me briefly review reasons for attributing certain basic traits of narcissism to the public behavior of Donald Trump.

In A Clear and Present Danger: Narcissism in the Era of Trump, co-editors Steven Buser and Leonard Cruz list a number of Trump's statements demonstrating the narcissistic trait of grandiosity with regard to his own power (xv-xvii). In addition, Trump's public self-portrayal reveals classic traits of narcissism: an incapacity to relate to the feelings of others (Symington 18), a sense of entitled specialness (Lowen 125-26), cruel use of power (Moore 272-73) and obsession with one's image. His callousness about separating children from their parents bears witness to his lack of empathy and his cruel use of power (Ainsley and Bennett). His efforts to place himself above the law and block the Mueller probe testify to his sense of entitled specialness (Benac et al.). His constant attacks on the free press, among other implications, reflect his obsession with his image. Trump's exhibiting of these traits is so extreme that Craig Malkin raises the question of whether he suffers from "malignant narcissism," a term coined by Erich Fromm and developed by Otto 
Kernberg to describe totalitarian leaders like Hitler, Kim Jong-un, and Vladimir Putin, all of whom seek the total power of a monotheistic god (57-58).

Clarifying the connection between absolute power, like that attributed to God the Father almighty, and the support of Trump's base for a narcissistic leader is the heart of this inquiry into an aspect of what in the psyche of many Americans has not been brought to consciousness and is being lived out in the fate of living with Trump's presidency. When referring to God, I am referring to human projections onto divinity, what Jung calls the God image.

The German philosopher Ludwig Feuerbach, absent the concept of the unconscious, argues in 1841 in The Essence of Christianity that people create gods in their own image. Almost exactly a hundred years later Jung writes that people don't create, but rather choose images of divinities ( $C W 11$, par. 143). He makes this distinction because he wants to insist on unconscious powers overwhelming human egos leading to projections of divinity, but wants also to recognize that the images do not communicate the reality of the unconscious forces themselves. He writes: "Though our choice characterizes and defines 'God,' it is always man-made, and the definition it gives is therefore finite and imperfect. ... The definition is an image ..." $(C W 11$, par. 144). He writes further that the characteristics we ascribe to our gods are unconscious projections, as in the absorption of the historic Christ in "archetypal projections upon him" (CW 11, par. 228).

A striking feature of Trump's supporters has been the fealty of fundamentalist Christians, even in the face of the sexual scandals and suspicions of economic corruption that keep haunting Trump's image. Trump himself refers gratefully to their support in his speech accepting the nomination of the Republican Party for President: "At this moment I would like to thank the evangelical community because I'll tell you what, the support they've given me, and I'm not sure I deserve it . . . [laughter] has been so amazing and has had such a big reason for me being here tonight. [Applause] True, so true" (Beckwith). The surprising affirmation by these self-identified Christians of Trump may be connected to an unconscious conditioning concerning man-made, imperfect images of God the almighty Father as narcissistic. Christianity, a religion whose very name indicates the centrality of Christ, has a long history of incorporating the almightiness of the God of the Hebraic religion from which Christ arose. The second century Old Roman Creed (a short predecessor of the later Apostles' Creed), the Nicene creed established during the First Council of Nicaea in the early fourth century, its amendment later that century at the First Council of Constantinople, and the earliest record of the Apostles' Creed toward the end of the fourth century all extol God the Father almighty. The Apostles' Creed, for example, begins, "I believe in God, the Father almighty. ..." As Vladislav Solc and George J. Didier explain in Dark Religion: Fundamentalism from the Perspective of Jungian Psychology, "Creed prescribes and proscribes what is to be believed and what is to be rejected based on a frame provided by those in authority" (45). Almightiness, that is, limitless power, characterizes the man-made, imperfect image of the Judeo-Christian God the Father.

The image of a monotheistic God as almighty Father did not always appear as kindly. This God is imaged using power arbitrarily as in the testing of Job and demanding the sacrifice of Isaac; punishing those who defy him as in the destruction of Sodom and Gomorrah; and insisting on being adored as in his first commandment given to Moses: "I am the Lord thy God, thou shalt have no other gods before me." Nathan Schwartz-Salant 
recognizes these manifestations of narcissism in his discussion of what he calls the black magician. He says this figure:

represents that factor in the psyche that drives for control and exhibits extreme grandiosity. It insists upon total determinacy of events.... [R]eality is equated with its thoughts and needs, and the power to "know" and control is continually exhibited. This omnipotence simultaneously demands mirroring, without which its very existence is threatened. A good example of this quality is the dark side of the Old Testament Yahweh. (67, emphasis in the original)

The Old Testament Yahweh, whose "dark side" Schwartz-Salant describes in terms of narcissism, becomes in Christian ideology God the Father who so loved his only begotten son that he sends him to suffer and die for all mankind in order to appease Himself for their disobedience. The issue of obedience to the father occupies a pivotal position in Brown's Wieland.

Trump has manifested all the aforementioned "divine" traits: a need for his reality to be reality (e.g., insisting that the American Southern Border is under attack and in a state of national emergency); a need to control and have his will be the law (e.g., ordering border agents to separate children and parents of immigrants in spite of a court order making such separations illegal); a need to have his will fulfilled (e.g., firing one appointee after another); and a need to be adored (e.g., choosing to spend time again and again, after having been elected, at rallies with his mirroring crowds). Elizabeth Mika characterizes malignant narcissists as having "an insatiable drive for power and adulation" (299). Vindictiveness, as in punishing enemies, is a defining trait of malignant narcissism (307). Trump's character-assassination of persons formerly associated with him, such as his former lawyer, Michael Cohen, and his firings of FBI Director James Comey and Deputy Director Andrew McCabe illustrate his punitiveness. The timing of the firing of McCabe so as to prevent his receiving a pension illustrates his vindictiveness. His ragefulness is documented in painful detail in Fear: Trump in the White House by Bob Woodward.

Trump's public personality parodies that of the image of God as almighty Father. The points of comparison make conscious that that version of God divinizes narcissistic traits. Divinizing narcissistic traits has consequences. Among them, arguably, is that persons socialized in religions divinizing narcissism unconsciously grant to human fathers and leaders powers claimed by narcissists and expect those powers of them. Theirs will be the power to define reality, to judge what and who is good or bad. Theirs will be the right to be obeyed or else inflict punishment. Theirs will be the power to demand that reality manifest their will.

Remarkably, a version of such a god image is portrayed in a novel published in the first decade of America: Wieland, or the Transformation, An American Tale by Charles Brockden Brown. Jung's proposition that visionary artists bring to consciousness what lies unconscious in the collective psyche does not depend on the artist's having conscious understanding of that function. Authors do not intentionally draw revelations from the collective unconscious for collective edification any more than a dreamer consciously draws from his or her unconscious the dream needed to image a psychological situation requiring attentive reflection. The imaginative work, in this case, Wieland, contains materials emerging from the unconscious psyche and thus potentially communicates across 
centuries. Even though Brown does not describe his novel in terms of narcissism or the image of America, one may read his depiction of the rule of the father in the New World as not only undercutting the American sense of representing an exceptional ideal to be emulated, but also as rendering horrific a narcissistic understanding of God the Father almighty.

From the time of its discovery, America has been imagined by European immigrants as a New World, one in which colonists could escape societal evils in the lands being left. Think of the City on the Hill of John Winthrop or the words of President John Adams rescued by his son after he, himself, omitted them from his A Dissertation on the Canon and Feudal Law. The excised passage reads: "I always consider the settlement of America with reverence and wonder as the opening of a grand scene and design in Providence for the illumination of the ignorant and the emancipation of the slavish part of mankind all over the earth." Brown, a child of a Quaker family in pre-revolutionary Philadelphia, a teenager during the American Revolution, and a published novelist in 1798 was one of the earliest skeptics of this ahistoric dream of America. Yet he passionately cared about the promise of the new country. He dedicated his professional life to bringing the newly joined colonies into a coherent nation. Brown attempted almost singlehandedly to generate a common culture out of the disparate cultures of the American colonies. In 1798 in the former colonies there was no common language, no common religion, few passable roads, and differing economies-agricultural vs. manufacturing-with conflicting interests. Brown wrote fiction and an annual Register of contemporary events to try to forge a common culture and help birth a national soul. Wieland, or the Transformation, An American Tale, his first successful novel, was read and praised by Samuel Taylor Coleridge, John Keats, William Hazlitt, William Wordsworth, and Mary Shelley (Trubek).

In this novel Brown creates a family, the Wielands, descendants of a German immigrant, living in cultured domestic contentment in their Mettingen estate in rural Pennsylvania. Their serenity is interrupted by the return of a religious calling to the male head of the family. He had been born in Europe to a father who had been disinherited because he had defied his aristocratic father by marrying a merchant's daughter. The conflictual nature of obedience to the father, seeded in Europe, originates the Wieland line. The outcast father and mother die when their son, referred to only by his surname, is of age to be apprenticed. His new master works him so relentlessly that he finds life gloomy and boring. His dissatisfied psychological state makes him a ready religious convert.

He happens upon a book written by a teacher of Albigensianism, a twelfth- and thirteenth-century form of the Manichean heresy that a good deity created the world of spirit and a bad deity created the world of matter. Brown thus introduces the idea of evil as metaphysically embedded in reality, not to be escaped in a supposed new world. Reading this Albigensian book, the apprentice Wieland learns of the Camisards who militantly opposed the imposition of Catholicism on the French people by Louis the XIV.

The book inspires Wieland to undertake a painstaking study of the Bible, which he reads through a Camisard lens, a perspective, according to Brown, that prevents a critical grasp of relationships: "Every fact and sentiment in this book were viewed through a medium which the writings of the Camisard apostle had suggested. [Wieland's] constructions of the text were hasty, and formed on a narrow scale. Every thing [sic] was viewed in a disconnected position. One action and one precept were not employed to 
illustrate and restrict the meaning of another" (15). This characterization faults individualistic interpretations of the Bible, that is, interpretations not guided by previous authority. The prevalence of such interpretations was partly a consequence of the spirit of individualism sweeping Europe (partially through the theories of John Locke whose writings were available and known in early America), a spirit undercutting obeisance to authority. Wieland's being the grandson of a defied, punitive patriarch and his internalization of Camisard religious teachings thus form him into a representative of the psychological conflict concerning patriarchal authority - that of church, state, and family-informing his times. Brown's focus on Wieland's inability to see interrelationships, a failing of narcissists, links this conflict to narcissism.

Gripped by a religious conversion, Wieland becomes beset by the conviction that God wills him to spread the gospels to the "unbelieving nations" (16). This experience of being directly charged by God the Father can be read as Wieland's unconscious coping with the authority conflict of father and son that he has inherited. When his apprenticeship ends, he takes his savings and immigrates to Philadelphia, intending to teach the gospels to the peoples known as Indians. Upon his arrival, the reputed savagery of his intended pupils gives him pause. Since land is cheap, he buys a farm and uses African slaves to tend it. After fourteen years of success, he marries a "meek" woman, enjoys leisure while others work his farm, and returns to Bible reading.

This history evokes aspects of the history of immigrant Americans up to the time of Brown's writing: the European legacy of disinherited aristocracy, the practice of apprenticeship, the religious wars between Roman Catholics and Protestants, immigration to the New World, and the religious fervor forming the spiritual background of parts of the European settlement of America. Most significantly, it portrays the development of material wealth and leisure through the use of America's cheap resources and the labor of indentured servants and slaves. It highlights the material prosperity that replaces the religious mission with which the journey to New England and mid-Atlantic states such as Pennsylvania began.

On his resumption of Bible-reading, Wieland's sense that God has called him to convert the Indians returns, and after much struggle he leaves his wife and children to preach. He is met with insuperable obstacles. In Brown's words, "His exhortations were attended with no permanent success. ... The license of savage passion, and the artifices of his depraved countrymen, all opposed themselves to his progress" (17-18). When he believes his task to be hopeless, he gives it up and returns to his farm where he is haunted by his not having fulfilled the divine command of God the Father. He builds a small temple on a hill reminiscent of Governor Winthrop's city on a hill, Winthrop's image of the European settlement of America - a shining image of God's people for all the world to see. The elder Wieland goes to this temple twice daily to pray. He becomes progressively agitated, reluctantly explaining to his wife that

his peace of mind was flown, in consequence of deviation from his duty. A command had been laid upon him, which he had delayed to perform. He felt as if a certain period of hesitation and reluctance had been allowed him, but that this period was passed.... [A]ll that remained was to endure the penalty. (20)

With great anguish, he expects this penalty to be a "strange and terrible" death (20). 
Wieland dreads punishment for having failed in his divinely assigned mission, and indeed the plot suggests that he is dreadfully punished. When his anxiety has reached fever pitch, he goes at midnight as is his custom to pray at the temple. But there, in his sacred temenos, he suffers a loud explosion followed by a suffusing light that leaves his clothes in cinders and himself horribly burned. Found and returned to his home, he suffers fever, delirium, and crawling putrefaction that literally drives everyone from the house as he dies.

Brown accounts for his death as a case of spontaneous combustion and even provides a footnote verifying the existence of such in a published case in 1783 . Metaphorically, guilt over his failure to obey his understanding of God's will, that is, his failure to live his life converting "unbelieving nations," destroys Wieland. His dying of such putrefaction that others could not remain near him evidences for those he leaves behind, including his son, Theodore, the fate of those disobeying God the Father.

Brown's novel then turns to prognostication through the characters of the dead Wieland's children, his daughter Clara who narrates the story, and Theodore who is referred to as "Wieland" throughout the rest of the novel.

Alongside the religious plot, Brown twists and makes thematic use of a common subject of the eighteenth-century novel, male attempts to seduce women. ${ }^{3}$ Brown, himself a feminist influenced by the writings of Mary Wollstonecraft, creates a seducer who only plays at seduction in order to test the courage of his victim, Clara Wieland. The pretend seducer is Carwin, a European who secretly is escaping from enemies he made through his nefarious ventriloquist practices of mimicking and projecting others' voices. Seen through the Narcissus myth, his character is an eerie inversion of Echo into an initiator of words never spoken by the persons being imitated. He is a living carrier of a false inner voice, anticipating the fourth generation Wieland's - Theodore's - future mystical delusion. He practices imitating others' voices to get out of various dilemmas and thus creates illusory experiences for Wieland, for Wieland's friend - Henry Pleyel — and later for Clara herself.

Carwin joins the little society of Mettingen. That society consists first of Theodore, who marries Catherine Pleyel, with whom he has four children. They adopt an orphan, Luisa Conway. Catherine's brother, Henry Pleyel, a dear friend of Theodore's and an unannounced admirer of Clara, becomes a constant visitor. Together Wieland, Catherine, Henry, Clara, and Louisa compose a social group with leisure to convert the temple on the hill into a salon where they converse about books arriving from Europe and, in general, about philosophical and cultural matters. They are a test group for the rationality of man celebrated by Deism.

Carwin's arrival adds the spice of an outsider's personality to their idyllic, middleclass life in rural Pennsylvania. He is welcomed to the group through Henry Pleyel. On the run, Carwin takes refuge in the vicinity of Mettingen and there encounters Pleyel who introduces him to the Wieland family society. As a ventriloquist, he imitates others' voices for the thrill of power. His purpose in hiding in Clara's closet, for example, is not to jump out and rape her but to terrify her with fear of murderers planning her death. In this way Brown subordinates the lust force, prominent in seduction narratives such as Pamela and Clarissa by Samuel Richardson, and the contemporary early American best seller, Charlotte: A Tale of Truth by Susanna Haswell Rowson, to sexless enjoyment of sadistic power. Carwin indulges this perverse pleasure by creating distant conversations that convince Pleyel and Theodore that Clara is sexually involved with him. Brown's improvising on the common subject matter of contemporary English novels is yet another 
implicit argument that the "New World" is constituted with cultural elements of the "Old." By depicting the European roots of the characters and their culture Brown insists on the New World's being permeated with the European past, particularly its religious heritage.

The conclusion of the novel dramatizes the role of religion in corrupting fatherhood when filtered through American narcissistic individualism. Clara, driven to near-despair by her loss of reputation and of Pleyel's respect through Carwin's antics, discovers, to her horror, her beloved sister-in-law Catherine dead in her bed. She immediately afterwards learns that her four nieces and nephews, as well as Luisa Conway, have also all been found brutally murdered. For a while she is protected from discovering who the murderer is, but eventually is devastated to learn that the killer is her brother, the pious and rational Theodore Wieland. He calmly affirms these killings in court as his fulfillment of a command he heard from the voice of God. He publicly prays,

"I thank thee, my Father, for thy bounty; that thou didst not ask a less sacrifice than this; that thou placedst me in a condition to testify my submission to thy will! What have I withheld which it was thy pleasure to exact? Now may I, with dauntless and erect eye, claim my reward, since I have given thee the treasure of my soul" (189).

Theodore Wieland's relation to fathering as revealed in his actions and speech testifies to his understanding of God the Father. He imagines the God whom he addresses as "Father" to desire his murdering his wife and children. Without purpose or spiritual claims of their own, his spouse and children exist in his mind only as appurtenances to the meaning of his life. Depriving them of their lives, he assumes, earns him God's reward. His belief in this revelation depends on the assumption that individuals could know God's will and thus on the cultural development of individualism that characterized Americans' understanding of their rights and freedoms. Ian Watt, in his perceptive history of the development of the novel, explains that the rise of individualism differentiated the eighteenth century. He writes,

[W] can say that the novel requires a world view which is centred on the social relationships between individual persons; and this involves . . . individualism, because until the end of the seventeenth century the individual was not conceived as wholly autonomous, but as an element in a picture which depended on divine persons for its meaning, as well as on traditional institutions such as Church and Kingship for its secular pattern.

The community at Mettingen represents the replacement of the authority of church and king with human reason, and Brown depicts it as being taken over by irrational beliefs concerning God the Father. Wieland enacts the murderous father he believes God to be.

Wieland is an early American version of Narcissus in his infatuation with his image and in his unrelatedness to the welfare of others. Toward the end of the novel, he escapes incarceration and returns to Mettingen to complete what he perceives to be his divine mission by murdering his sister, Clara. There he encounters Carwin who has returned to explain to Clara his role as ventriloquist in the recent history of their society and to insist that he had no part in Wieland's heard voices. Carwin persuades Wieland that the voices he heard were not of divine origin. At first, Wieland is devastated. In the words of the novel, "his respiration became hoarse, like that of a man in the agonies of death" (249). He sends Carwin away and for a moment seems to have let go of his belief that he has enacted 
God's will even as he clings to the rectitude of his motives. His countenance a portrait of sorrow, Wieland asserts his belief in the virtue of his murders as he reassures his sister. He says, "Once it was the scope of my labours to destroy thee, but I was prompted to the deed by heaven, such, at least, was my belief. . . . I am pure from all stain. I believed that my God was my mover! . . . In thy sight, Being of beings! I am still pure. Still will I look for my reward in thy justice" (253-54). This claim that unconsciousness of having been deluded frees him from guilt and does not interfere with his murderous acts deserving divine reward reflects an old European heritage. He is a cultural descendant of Sophocles' Oedipus who thought himself innocent because of the virtue of his motives and his unconsciousness of who it was he murdered at the crossroads and married as his queen. Again, the inescapable legacy of Europe appears in the character of American descendants of European immigrants.

Even though Carwin dissuaded Wieland for a moment from believing that the voice he heard was God's, Wieland cannot let go of his image as dutiful son of God the Father, and he soon persuades himself that Carwin is a demon, that he, himself, has acted as an obedient child of God, and that God's original command to kill his family must still be fulfilled. As he threatens Clara once again, Carwin does, in fact, imitate God's voice. He projects it as coming from above, and cries in a thunderous voice to "Hold! . . Man of errors! Cease to cherish thy delusion; not heaven or hell . . . have misled thee to commit these acts. Shake off thy frenzy, and ascend into rational and human. Be lunatic no longer" (259). Believing as he does in personal divine revelation, Wieland is crushed by this obliteration of the image of himself as divine executioner and fatally stabs himself in the neck.

Carwin's imitation of God's voice ironically preserves Clara's life while Wieland's authentic inner experience of what he believes to be God's voice leads to murder. Wieland's having heard God's voice command him to kill his family constitutes an immanent experience of God, the kind of experience that Jung and theologian John Dourley after him think is a religious conversion of the experience of the ego being overwhelmed by a numinous encounter with the unconscious. Jung refers to the discovery of the limitlessness within in an "enlightened individual's" relation to "the One who dwells within him, whose form has no knowable boundaries, who encompasses him on all sides, fathomless as the abysms of the earth and vast as the sky" (CW11, par. 758). Dourley comments on Jung's statement by asserting that the immanent experience of the numinous power of psyche leads to understanding of the transcendent:

In this profound text it should be noted that this sense of the divine moves from within, the immanental, to a sense of the all-encompassing transcendent. Without the within the divine without remains ambivalent. . . - This external divinity is a heteronomous divinity. It can only act as a repressive and authoritarian imposition on the human and so [as] the extreme form of an alienation between the divine and a humanity unconscious of the inner origin of all the Gods none of whom are wholly other or wholly foreign to the humanity from whose depths they are born.

As with Cambray's translation of emergence theory into psychological equivalents, Dourley's appropriation of Jung's paradigm concerning ego encounters with the "divine" 
in unconscious psyche assumes positive development, an assumption that Wieland's inner experience of God's voice belies. The "divine" voice which commands Wieland to arrogate to himself the power of deciding life and death enables him consciously to kill in obedience to God's command, unconsciously to identify with his image of God the Father. He has the dual satisfaction of behaving as virtuous son deserving reward and of wielding divine power over life. Theodore Wieland attempts to resolve the father-son conflict concerning obedience through identifying with both the obedience required of the son and the power over life possessed by the father. This attempted resolution, rather than leading to positive evolution, results in wholesale slaughter.

Wieland experiences a profound inner relationship with the divine, but this relationship does not prevent the God image from acting as a "repressive and authoritarian imposition on the human" as in Dourley's description of the relation to a transcendent divinity without the inner experience of an encounter with one's unconscious. Wieland, as a visionary literary expression of the unconscious in response to a blindness in collective consciousness of Americans, both demonstrates the murderous underbelly of narcissistic worship of an almighty God and the liability of inner experiences of such a God image to horrific inflation.

Brown's Wieland records a multigenerational repetition of pairs of fathers and sons struggling with whether and how to obey their fathers, human and divine. Theodore's fate may be seen as an illustration of what Kimbles some two hundred years later was to name a phantom narrative, that is, an unresolved psychological conflict inherited by successive generations and acted out as if descendants were caught in a script. The originating patriarchal Wieland, an aristocrat, disinherits his son who defies him by marrying a merchant's daughter. The disowned son begets Theodore Wieland's father who experiences the conflict concerning authority not with his biological father who died when he was young but with his acquired image of his divine Father. He believes himself divinely commanded to be God the Father's emissary and comes to America to fulfill God's command to preach the Bible to the "unbelieving nations." Failing successfully to do so, he dreads divine punishment for his disobedience and in fact mysteriously either is divinely destroyed or psychologically self-destructs. His son Theodore apparently unconsciously inherits his father's religious experiences and fantasies in his seeking to know God the Father's will and to execute it. He thinks himself successful in obedience to God where his father had failed, but ultimately realizes he has murdered his family out of a self-delusion. Having esteemed himself for having killed his wife and children at the apparent command of God, he is devastated when deprived of this gratifying image of himself. He then, like his father-and their psychological ancestor, Narcissus, who iconically failed to become one with his self-image - also self-destructs. Brown's novel does not resolve the conflicts over authority between fathers and sons, human and divine, but rather articulates a psychological step toward a resolution. He climaxes the themes of his novel with Clara's wishing that "Wieland had framed juster notions of moral duty and of the divine attributes ..." (276, emphasis added).

I propose that the surfacing of Trump as president raises for Americans the issue of framing "juster notions of . . divine attributes." Kimbles describes recurrent phantoms as "images of group life that reflect the specific dynamics operating in groups and individuals through various social attitudes and structures that are alive in current events" (20). Current technology has provided literal images of the group life of Trump supporters during 
political rallies, showing them worshipful of a narcissistic leader claiming almighty power. At the rallies, they affirm Trump's every assertion, an enthusiastic mirroring of him as he makes impossible claims that he is the only one who can protect America, the only one who can "fix the system," the only one who can "make possible every dream you've ever dreamed" (Benen). As he repeatedly lays claim to almightiness, his supporters meet him with roars of approval. His ascendance to the presidency reveals the ongoing enthrallment of a significant portion of Americans with a fantasy of the almighty Father. Mika claims that "the people see in him their long-awaited savior and a father substitute" and that "through the process of identification [they] absorb his omnipotence and glory and imagine themselves as powerful as he is" (305).

Brown's depiction of Theodore Wieland anticipates Trump's impassioned supporters. Theodore imagines that God wills the deaths of those he is responsible for and that He will reward him as a good son for murdering them much as Trump's followers imagine that Trump is willing to have immigrants seeking asylum die in their home countries and that he will reward those who elect him by preserving America's resources for their use. Theodore imagines that he is sacrificing to divine authority in murdering the appointed victims when he is in fact enjoying the traditionally divine prerogative of taking lives much as extremist Trump supporters experience the satisfaction of violently attacking and ousting protesters in obedience to Trump's command at rallies or of actually killing those opposed to Trump's support of racism as in the murder of the counter-protestor at the White Nationalist rally in Charlottesville, Virginia, Heather Heyer, in August, 2017 (Stolberg and Rosenthal). Divinizing narcissistic traits transfers to worshipping narcissistic leaders, apparently providing a sense of legitimacy to enacting violence.

Brown's critical depiction of the narcissistic interaction of the father-son relationship implicitly calls for a reconceiving of the relationship between humans and our projected divinity, perhaps even relinquishing the projection of all-powerful parent altogether. Dourley outlines Jung's development of the image of God the Father: "[Jung's] psychology depicts the Father as the wholly undifferentiated source of creation in a psychological age prior to a sense of individuality. The Son represents the evolution of consciousness ..." (150). Jung envisions the trinity as an evolution of human projections upon our god-images. The conclusion of Brown's novel offers a similar call for evolution of the image of God the Father: the development of "juster notions of moral duty and of the divine attributes" (276).

Jung writes of the immaturity of conceiving of God as a loving parent: "Faith . . . tries to retain a primitive mental condition on merely sentimental grounds. It is unwilling to give up the primitive, childlike relationship to mind-created and hypostatized figures; it wants to go on enjoying the security and confidence of a world still presided over by powerful, responsible and kindly parents" ( $C W 11$, par. 763). How the image of God may be reimagined so as to surrender both fantasies of parental almightiness - its powers to punish and reward, and its powers lovingly to protect-poses a profound psychological challenge raised by Trump's election. Juxtaposing this challenge with Brown's rendering of the phantom narrative of conflict between fathers and sons conveys a need to transform the understanding of authority partially through recalling projections on divinity. The call for fundamental change voiced in Wieland has become ever more urgent - to form "juster notions of moral duty and of the divine attributes." 
This essay has attempted to weave together a number of threads to propose that a vein of American culture has unconsciously divinized certain narcissistic traits through worship of a necessarily imperfect image of God as a narcissistic almighty Father demanding control and obedience - a Father who will reward subservient worshippers and punish any who oppose his will. Brown's novel Wieland portrays human relationships with such an imagined god at the beginnings of America. Trump's impassioned supporters elected a man who attempts to embody such an authority. Because the narcissism in this image of God the Father almighty is cloaked in religious garb, the worshipping of narcissistic traits has remained unconscious, unexamined. The election of Trump to the American presidency has prompted this analysis identifying the unconscious divinization of narcissistic traits. Thinking of God the Father's almightiness as suffused with narcissism will appear blasphemous to those who do not accept the idea that the image of God is a projection issuing from human imperfections. As asserted earlier, the consequences of unconscious materials becoming conscious are uncertain and in this case are dependent upon the collective psychological capacity to accept responsibility for what has been projected.

The effort to discover a basic aspect of what has lain unconscious in the collective psyche enacts a Jungian "notion of moral duty." Jung writes of the power of individuals recognizing the evil within ourselves to mitigate the evil in the world: "Such a man knows that whatever is wrong in the world is in himself, and if he only learns to deal with his own shadow he has done something real for the world. He has succeeded in shouldering at least an infinitesimal part of the gigantic, unsolved social problems of our day" ( $C W$ 11, par. 140). Jung prescribes the development of self-knowledge as necessary for dealing with the "wholesale murderer" in man ( $C W 11$, par. 86). Trump's election spurs collective development of such self-knowledge. Theodore Wieland and his narcissistic relationship with his imagined grandiose, divine Father offers Americans a mirror from which to gain self-knowledge, an opportunity to withdraw narcissistic projections from a multigenerational image of God, and a challenge to accept as a collective our responsibility for human murderousness.

\section{Contributor}

Inez Martinez, Ph.D., is a writer. She writes psychological criticism of literature. She contributed a Foreword to Fanny Brewster's Archetypal Grief. She also has published creative writing including fiction, poetry, and a play. Most recently, a selection of her childhood poems inspired artwork by Toby Needler resulting in the book Childful Moments published in 2019.

\section{Notes}

${ }^{1}$ The American experience of elevating a dictatorial leader occurs during an international paroxysm of handing over power to such men. See, for example, "Crazy like a Fox vs. Crazy like a Crazy" in which Michael J. Tansey points to Trump's admiration of dictatorial leaders in North Korea, Syria, Russia, the Philippines, and Turkey (115).

2 I propose there, using Singer and Kimbles' theoretical tool of a cultural complex, that the sense of victimization suffered by this group is a complex stemming from the loss of privileges accorded to whiteness and maleness from the beginnings of American history. 
Singer and Kimbles describe cultural complexes as similar to individual complexes, "tend[ing] to be repetitive, autonomous, [to] resist consciousness, and [to] collect experience that confirms their historical point of view" (6). Naming the sense of victimization of Trump's base a complex indicates that these people are not consciously in control of the passions of resentment, anger, perhaps hate, and cannot become so until they deal consciously with the irrationality of the expectation that whiteness and maleness should confer privileges. When members of a privileged group feel victimized by the erosion of their privileges, their wound, based on a sense of entitlement and unrelated self-interest, exposes narcissism.

${ }^{3}$ Seduction was the theme of the first best-selling novel in early America published in American edition four years prior to Brown's Wieland. Charlotte: A Tale of Truth by Susanna Haswell Rowson was a cautionary tale depicting the seduction of a young woman who became pregnant and died, abandoned, in the aftermath of childbirth.

\section{Works Cited}

Adams, John. A Dissertation on the Canon and Feudal Law. teachingamericanhistory.org/library/document/a-dissertation-on-the-canon-andfeudal-law.

Ainsley, Julia, and Geoff Bennett. “Trump's support of renewed child separation policy led to collision with Nielsen." 8 Apr. 2019, www.nbcnews.com.

Beckwith, Ryan Teague. “Acceptance Speech at the Convention.” 22 July 2016, Time.com.

Benac, Nancy, et al. “Mueller reveals Trump's attempts to choke off Russia Probe." 19 Apr. 2019, www.apnews.com.

Benen, Steve. “Trump says he's 'the only one' who can protect America.”12 Oct. 2016, www.msnbc.com.

Brown, Charles Brockden. Wieland or the Transformation, An American Tale. 1798. Dolphin, 1962.

Cambray, Joseph. Synchronicity: Nature \& Psyche in an Interconnected Universe. Texas A\&M UP, 2009.

Cruz, Leonard, and Steven Buser, editors. A Clear and Present Danger: Narcissism in the Era of President Trump, rev. ed., Chiron Publications, 2017.

--. "The Goldwater Rule: Crossing the Border of Assessing Public Figures. Cruz and Buser, pp. xiii-xix.

Dourley, John P. Jung and His Mystics. Routledge, 2014.

Feuerbach, Ludwig. The Essence of Christianity. 1841. Translated by Marian Evans, John Chapman, 1854.

Frank, Thomas. Listen, Liberal. Metropolitan Books, 2016.

Goldstone, Lawrence. “America’s Relentless Repression of Black Voters.” The New Republic. 24 Oct. 2018, https://newrepublic.com.

Jung, C. G. The Collected Works of C. G. Jung. General editor, Sir Herbert Read et al., translated by R. F. C. Hull, 2nd ed., Princeton UP, 1953-1979. 20 vols. Bollingen Series 20. 
Kimbles, Samuel. Phantom Narratives: The Unseen Contributions of Culture to Psyche. Roman \& Littlefield, 2014.

Lee, Bandy, editor. The Dangerous Case of Donald Trump. A Thomas Dunne Book, 2017.

Lowen, Alexander. Narcissism: Denial of the True Self. Macmillan, 1983.

Malkin, Craig. "Psychological Narcissism and Politics." Lee, pp.51-68.

Martinez, Inez. “Trump's Base, Ahab, and the American Dream.” Journal of Jungian Scholarly Studies, vol. 13, 2018: pp. 3-17.

Mika, Elizabeth. "Who Goes Trump? Tyranny as a Triumph of Narcissism.” Lee, pp. 298-318.

Moore, Robert. "Come, There Is Much that We Can Yet Do.” Cruz and Buser, pp. 269-74.

Rowson, Susanna Haswell. Charlotte: A Tale of Truth. 1791. Ed., William S. Kable. Charles E. Merrill, 1970.

Schwartz-Salant, Nathan. Narcissism and Character-Transformation: The Psychology of Narcissistic Character Disorders. Inner City Books, 1982.

Singer, Thomas, and Samuel L. Kimbles, editors. The Cultural Complex: Contemporary Jungian Perspectives on Psyche and Society. Brunner-Routledge, 2004.

Singer, Tom. "Trump and the American Selfie: Archetypal Defenses of the Group Spirit." Cruz and Buser, pp. 17-47.

Solc, Vladisav, and Geroge J. Didier. Dark Religion: Fundamentalism from the Perspective of Jungian Psychology. Chiron, 2018.

Sophocles. The Oedipus Cycle. Translated by Dudley Fitts and Robert Fitzgerald, Harvest, 1939.

Stolberg, Sheryl Gay, and Brian M. Rosenthal. "Man Charged After White Nationalist Rally in Charlottesville Ends in Deadly Violence." 12 Aug. 2017, www.nytimes.com.

Symington, Neville. Narcissism: A New Theory. Karnac Books, 1993.

Tansey, Michael J. “'Crazy like a Fox' vs. 'Crazy like a Crazy.'” Lee, pp. 110-25.

Trubek, Anne. “Our Founding Novelist.” Humanities, vol. 31, no. 4, neh.gov/humanities/2010/januaryfebruary/feature/our founding novelist.

Watt, Ian. The Rise of the Novel. U of California P, 1965.

Winthrop, John. "A Model of Christian Charity.” 1630. The Winthrop Society. www.winthropsociety.com.

Woodward, Bob. Fear: Trump in the White House. Simon and Schuster, 2018. 